\title{
Effect of age and of performance parameters on CK, LDH and AST activities in plasma of standardbred horses during exercise
}

\author{
A. Lindner ${ }^{1}$ and A. Hatzipanagiotou ${ }^{2}$ \\ ${ }^{1}$ Arbeitsgruppe Pferd, c/o Arno Lindner, Bonn, Germany \\ ${ }^{2}$ Section of Animal Production, School of Agriculture, Aristotelian University of Thessaloniki, Greece
}

\begin{abstract}
Summary
The objective of the study was to examine whether age, racing time record, $v_{4}$ or $v_{200}$ of standardbred horses had an effect on the changes of $\mathrm{CK}, \mathrm{LDH}$ and AST activities in plasma during exercise $\left(\mathrm{v}_{4}\right.$ and $\mathrm{v}_{200}=$ velocities run under the defined conditions inducing $4 \mathrm{mmol} / \mathrm{l}$ blood lactate concentration and 200 beats $/ \mathrm{min}$ ). For this purpose 15 standardbred horses were submitted to a standardized exercise test (SET). The SET consisted of four or more runs depending on when the blood lactate concentration of a horse exceeded $4 \mathrm{mmol} / \mathrm{l}$. Speed in the first run was 6 $\mathrm{m} / \mathrm{s}$, and it was increased by $1 \mathrm{~m} / \mathrm{s}$ for each run. The blood lactate concentration measured after each run and the mean heart rate during each run was plotted against running speed to derive $v_{4}$ and $v_{200}$ from the blood lactate- and heart rate-running speed relation.

The median values of the enzyme activities in plasma of two-year old horses increased significantly during the exercise test. The median $\mathrm{LDH}$ and AST activities in plasma of the horses older than two years increased significantly too, but at later runs than in plasma of two-year old horses. The median CK activity in plasma of horses older than two years did not change during the test. The comparison of the median enzyme activities in plasma of horses at different sampling times demonstrated that the difference in age only showed up in the CK activity after the 4 th run. There was no significant relationship between the racing time record, $v_{4}$ or $v_{200}$ and the absolute or relative difference of the change of the activities of the enzymes measured.
\end{abstract}

Keywords: $\quad$ muscle enzymes, horse, blood, exercise, training, age Wirkung des Alters und bestimmter Leistungsparameter auf CK, LDH und AST Aktivitäten im Plasma von Trabrennpferden bei
Belastung

Ziel der Untersuchung war es zu prüfen, ob das Alter von Trabrennpferden, ihr Rennrekord, ihre $\mathrm{v}_{4}$ oder ihre $\mathrm{v}_{200}$ einen Einfluß haben auf das Ausmaß der Veränderungen der CK-, LDH- und AST-Aktivitäten im Plasma der Tiere $\left(\mathrm{v}_{4}, \mathrm{v}_{200}=\right.$ Geschwindigkeiten, die rechnerisch $4 \mathrm{mmol} / \mathrm{I}$ Laktat im Blut und 200 Herzschläge/min hervorrufen, wenn sie unter den definierten Testbedingungen gelaufen werden). Dafür wurden 15 Trabrennpferde einem Belastungstest unterzogen. Der Belastungstest bestand aus mehreren Intervallen. Zwischen zwei Intervallen lagen immer drei Minuten Pause. Die Blutprobe wurde innerhalb der ersten Minute nach Ende eines Intervalls aus der Vena jugularis gewonnen. Im ersten Intervall liefen die Pferde 6,0 m/s; in jedem weiteren Intervall erhöhte sich die Geschwindigkeit um jeweils $1 \mathrm{~m} / \mathrm{s}$. Der Belastungstest wurde beendet, wenn die Laktatkonzentration im Blut $4 \mathrm{mmol} / \mathrm{l}$ überschritt. Die Herzfrequenz jedes Pferdes wurde während der Belastungs tests kontinuierlich mit einem Herzfrequenzmeßgerät gemessen. $v_{4}$ wurde mit einer exponentiellen Regression, $v_{200}$ mit der linearen Regression berechnet.

Die Medianwerte aller Enzyme stiegen bei den 2-jährigen Pferden während des Belastungstests signifikant an. Die Medianwerte der Plasmaaktivitäten von LDH und AST stiegen auch bei den Pferden, die älter als zwei Jahre waren, während des Belastungstests an aber später als bei den 2-jährigen Pferden. Die mediane CK-Aktivität stieg dagegen bei den älteren Pferden nicht an. Der Vergleich der Enzymaktivitäten im Plasma zwischen den 2-jährigen und den älteren Pferden zu verschiedenen Zeitpunkten der Blutentnahme während und nach dem Belastungstest zeigte signifikante Unterschiede nur in der CK-Aktivität und nur nach dem 4. Laufintervall: Die mediane Aktivität war höher bei den 2-jährigen Pferden. Zwischen Rennrekord, $\mathrm{v}_{4}$ und $\mathrm{v}_{200}$ und den Veränderungen der Plasmaenzymaktivitäten der Trabrennpferde während und nach Belastung gab es keine Beziehung.

Schlüsselwörter: Muskelenzyme, Pferd, Blut, Belastung, Training, Alter

\section{Introduction}

The activity of CK (Creatine phosphokinase, E.C. 2.7.3.2), AST (Aspartate aminotransferase, E.C. 2.6.1.1), and LDH (Lactate dehydrogenase, E.C. 1.1.1.27) in blood plasma or serum is commonly used as an indicator of skeletal muscle damage in horses (Hatzipanagiotou et al., 1991, Lindholm 1987). However, any exercise of sufficient intensity induces elevations of these enzymes in plasma or serum without horses necessarily demonstrating clinical signs of muscle damage (Freestone et al., 1989, Islas et al., 1992, Rose et al., 1983, Siciliano et al., 1995, Snow et al., 1982). In several studies it has been shown that through conditioning the elevations of CK, LDH and AST after standardized exercise are lower than before conditioning (Anderson, 1975, Bent et al., 1991, Grün et al., 1977, Hambleton et al., 1980, Siciliano et al., 1995), while in others such effects could not be found (Freestone et al., 1989, Rose and Hodgson, 1982). The discrepancy very likely may be the result of more or less effective conditioning regimes. How- 
ever, also the rather large variations of the blood plasma enyme activities may influence results of studies.

According to several authors, measuring the extent of the changes of CK, LDH or AST activities in blood during or after standardized exercise may allow for assessing fitness of the musculoskeletal system of sport horses (Bent et al., 1991, Grün et al., 1977, Jeffcott, 1974, Rose and Hodgson, 1982, Szarska, 1994). However; no study was found in which the elevations of muscle enzyme activities in blood during standardized exercise were related to performance parameters of competition horses.

Therefore, the objective of this study was to examine whether age and several performance parameters of standardbred horses like racing time record, $v_{4}$ and $v_{200}$ had an effect on the extent of changes of CK, LDH and AST activities in plasma during exercise.

\section{Material and Methods}

\section{Horses and study design}

Fifteen standardbred horses in racing training were studied: 7 mares, 7 stallions, one gelding aged 2 to 7 years (mean \pm SD body weight: $460 \pm 36 \mathrm{~kg}$ ). All horses were from the same race stable and were being conditioned for racing since at least four months before the study. Seven of the horses raced during this period and had a time record. They were all older than two years. Six horses were two-year olds and were being prepared for their qualification races.

All exercise tests were done on a 1,000-m-long oval dirttrack, with posts as landmarks every $250 \mathrm{~m}$ to make it easier to drive at constant paces. During the tests, the drivers used a watch to set the pace. Before each test, the track was prepared to ensure regular lane conditions. All horses were tested on the same day within four hours under similar weather conditions (mean $\pm \mathrm{SD}$ of environmental temperature $21.6 \pm 2.5^{\circ} \mathrm{C}$, and of relative humidity $70.4 \pm 6.0 \%$ ).

The exercise test consisted of at least four runs over a differing number of laps at the track according to the speed of the run. The aim was to have the horses run for more than four minutes in each run and to always have them starting and stopping at the same place. In the first and second run horses trotted two laps, in all other runs three laps. Runs were separated by a period of three minutes. During this time horses were stopped, blood samples were taken and horses were walked away about $50 \mathrm{~m}$ from the start, then turned into the running direction and started again. The velocity required in the first run was $6 \mathrm{~m} / \mathrm{s}$. The speed was increased by $1.0 \mathrm{~m} / \mathrm{s}$ per run. The test was discontinued when the blood lactate concentration of the horses exceeded $4 \mathrm{mmol} / \mathrm{l}$. Velocity was maintained by the drivers who timed their progress, using 250-m landmarks on the track and a watch. Additionally, each run was timed by an independent observer with a stopwatch accurate to 0.1 seconds. The mean difference between requested and recorded speed was $-0.01 \mathrm{~m} / \mathrm{s}( \pm 0.08 \mathrm{SD}, \mathrm{n}=71)$. The largest single value difference was $0.2 \mathrm{~m} / \mathrm{s}$.
Before the test but after warm-up (6 min walking to the track and 5 min trotting on it), and within 60 seconds after each run, blood samples were collected for determination of lactate concentration. In addition, one blood sample was taken 10 minutes after cooling down at a slow trotting pace. The heart rate was monitored continuously during the test with a heart rate meter attached to the thorax of the horse (Polar Sport Tester). With the measured blood lactate concentration and running speed for each run of the tests the blood lactate-running speed relation was determined by exponential regression analysis.

The mean heart rate of each run was calculated considering the values recorded before dropping during the last 30 seconds of each run. With the mean heart rate and running speed for each run the heart rate-running speed relation was determined by linear regression analysis.

For blood collection into Na-heparinized evacuated tubes the Vena jugularis externa was punctured.

\section{Lactate analysis}

Twenty microlitres of blood was transferred immediately to vials with $200 \mu \mathrm{l}$ of $0.36 \mathrm{n}$ perchloric acid. Samples were centrifuged at $12,000 \mathrm{~g}$ for 5 minutes, and the supernatant was transferred to empty vials. Samples were stored at $4^{\circ} \mathrm{C}$ for up to 4 days until analysis, using an enzymatic test kit (Behring OSUA 40, Marburg, Germany). The intraassay coefficient of variation for this enzymatic method was $3.2 \%$ at a lactate concentration of $2.15 \mathrm{mmol} / \mathrm{l}$ and was $4.0 \%$ at a concentration of $4.4 \mathrm{mmol} / \mathrm{l}$.

Beginning with the third run, blood lactate concentration of horses after each run was measured on site with Accusport@ (Lindner, 1996). When the blood lactate concentration was above $4 \mathrm{mmol} / \mathrm{l}$ the exercise test was finished.

\section{$C K, L D H$ and $A S T$ analysis}

Samples were centrifuged within 30 minutes after collection at $10,000 \mathrm{~g}$ for 10 minutes. The plasma was transferred to empty vials and stored at $-20^{\circ} \mathrm{C}$ until analysis, using commercial test kits according to the recommendations of the German Clinical Chemistry Association. The intraassay and interassay coefficients of variation for the methods were all below $3 \%$.

\section{Driving accuracy of drivers}

The two drivers participating in this study were experienced, active race drivers. Before the study they were asked to demonstrate their ability to drive horses at defined constant paces. This was controlled by clocking their driving time every $1,000 \mathrm{~m}$ for a total of 5 different speeds $(6.90$, $7.41,8.00,8.70$ and $9.52 \mathrm{~m} / \mathrm{s}$ ) with 5 horses on two consecutive days. The mean difference between requested and driven speed was $0.12 \pm 0.12 \mathrm{~m} / \mathrm{s}(0.23,0.05,0.16,0.04$ and $0.10 \mathrm{~m} / \mathrm{s}$ for the five requested speeds respectively). 


\section{Statistical analysis}

Data of CK and AST were not normally distributed. Therefore all data are described with median, 10th and 90th percentiles. The Wilcoxon signed rank test was used to analyze the effect of trotting consecutive runs at incrementing speeds on plasma enzyme activities of horses of two years of age and older than two years of age. To determine whether data between the two age groups differed the Mann-Whitney U-test was applied. The relation between the extent of enzyme activities changes and racing time record, $v_{4}$ and $v_{200}$ was evaluated by means of the Spearman rank correlation test. The following differences were calculated to examine the extent of the changes:

- absolute difference $=$ value after 4 th run - value after warm-up
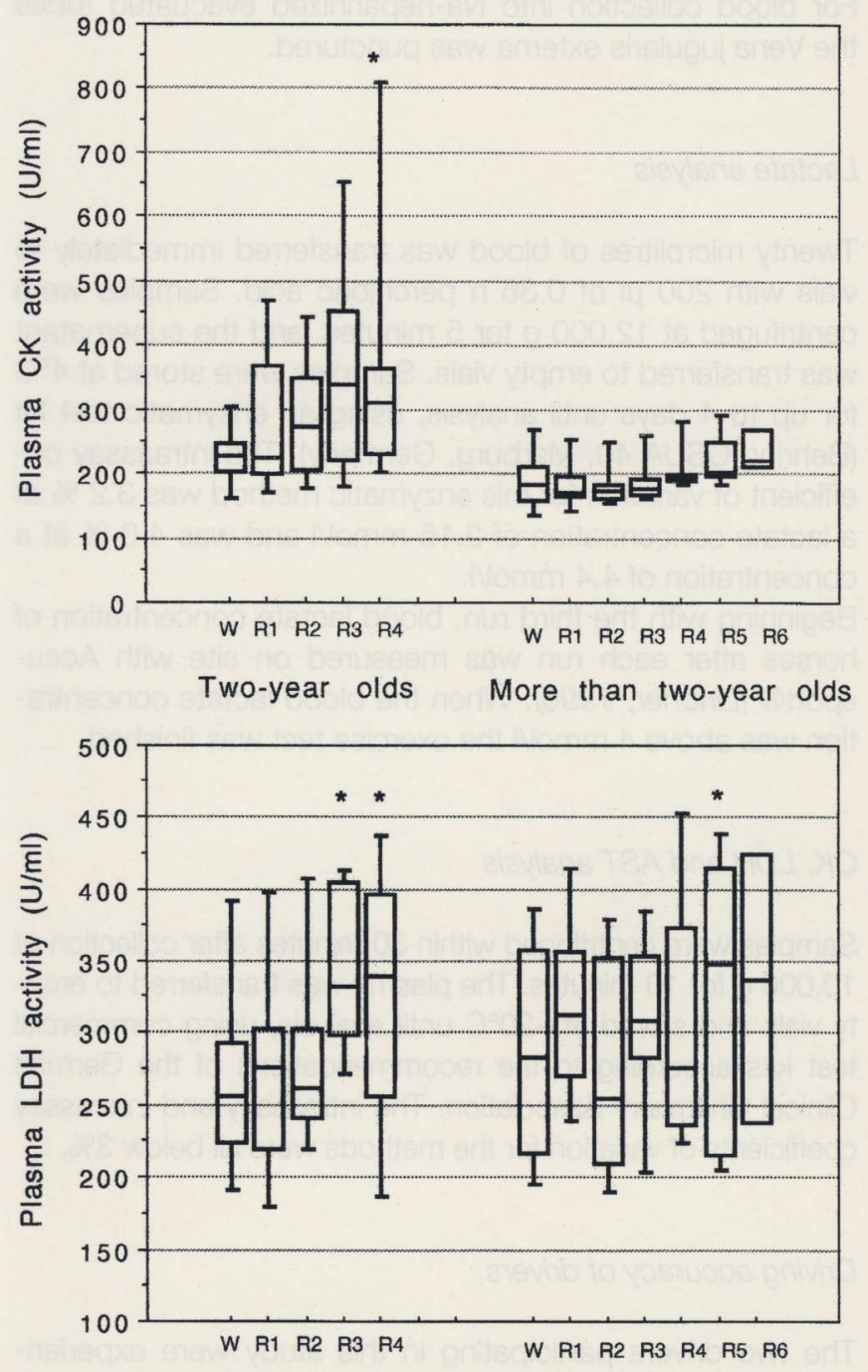

Two-year olds More than two-year olds
- relative difference $=$ value after run at which blood lactate concentration exceeded $4 \mathrm{mmol} / \mathrm{l}$ - value after warm-up. $p<0.05$ was accepted as significant for all statistical methods.

\section{Results}

All two-year old horses trotted four runs, six of the horses older than two years trotted five runs, and three of them trotted six runs until the blood lactate concentration was at or above $4 \mathrm{mmol} / \mathrm{l}$.

The median values of the enzyme activities in plasma of two-year old horses increased significantly during the exercise test (figure 1,2 and 3). The first enzyme to respond was AST, followed by LDH and finally also CK after the fourth run. The median LDH and AST activities in plasma of the horses older than two years increased significantly too, but at later runs than in plasma of two-year old horses (figure 2 and 3). The median CK activity in plasma of horses older than two years did not change during the test (figure 1).

The comparison of the median enzyme activities in plasma of horses at different sampling times demonstrated that only the CK activity, and only after the 4th run, differed between the two age groups (table 1): it was higher in plasma of two-year old horses than in plasma of older horses.

The group of horses older than two years had higher $v_{4}$ and $v_{200}$ values than the group of horses of two years of age $\left(p=0.01 ; 9.80 \pm 0.45 \mathrm{~m} / \mathrm{s}\right.$ vs $8.97 \pm 0.54 \mathrm{~m} / \mathrm{s}$ for $v_{4}$; $\mathrm{p}=0.06 ; 10.5 \pm 0.82 \mathrm{~m} / \mathrm{s}$ vs $9.50 \pm 0.82$ ). There was no significant relationship between the racing time record, $v_{4}$ or $v_{200}$ and the absolute or relative difference of the change of the activities of the enzymes measured.

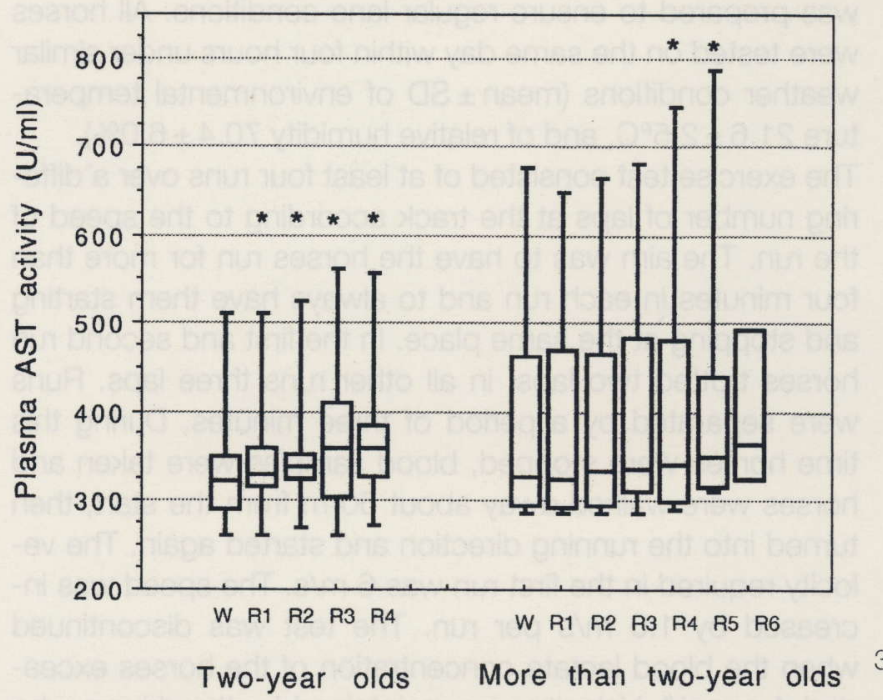

Fig. 1,2,3: Plasma CK (fig. 1), LDH (fig.2), AST (fig.3) activity of six two-year old and nine older standardbred horses during a standardized exercise test. (Median 10th, 25th, 75th and 90th percentiles; $W=$ after warm-up, R1, R2, R... = after 1st run, 2nd run, 3rd run...; ${ }^{*}=\mathrm{p}<0.05$ between this run and warm-up)

CK-, LDH- und AST-Aktivitäten im Plasma von sechs 2jährigen und neun älteren Trabrennpferden während eines standardisierten Belastungstests. (Median, 10-, 25-, 75-, und 90-Perzentile; $W=$ nach dem Aufwärmen, R1, R2, R3 ... = nach dem ersten Intervall, nach dem zweiten Intervall, nach dem dritten Intervall...; ${ }^{*}=p<0,05$ zwischen diesem Intervall und nach dem Aufwärmen) 


\section{Discussion}

Parameters derived from the blood lactate- and the heart rate-running speed relationship like $v_{4}$ and $v_{200}$ are determined to examine effects of conditioning and to estimate exercise tolerance capacity of horses (Harkins et al., 1993, Persson, 1983, Persson, 1997, Sloet van OldruitenborghOosterbaan et al., 1987). In this study the group of horses older than two years had higher $v_{4}$ and $v_{200}$ values than the group of horses of two years of age. This result agrees with the conclusions from a study recently published (Persson 1997).

The correlation between the racing time record and these two parameters was only significant for $\mathrm{v}_{4}(\mathrm{p}<0.001, r=-0.77$; faster horses $=$ less time for running one $\mathrm{km}$; for $v_{200}$ $p>0.05, r=0.18$; Lindner 1998). In several studies a good correlation between competitive performance level and $v_{4}$ has been shown (Persson et al., 1983, Sloet van Oldruitenborgh-Oosterbaan et al., 1987, Erickson et al., 1990, Auvinet et al., 1991, Casini and Greppi, 1996). In contrast, good correlations between competitive performance level and $v_{200}$ have not been observed yet. The results of this study support these observations.

For the objective of this study it is of importance that with $v_{4}$ and $v_{200}$ it was possible to distinguish between the two age groups defined (Lindner, 1998), and that the only enzyme which allowed this also was CK. This only holds when the values after the fourth run are compared.

The clear increase of the median values of all enzyme activities measured during the exercise test in the horses of two years of age and the reduced response in plasma of horses older than two years seems to reflect a musculoskeletal adaptation to exercise conditioning, but also could be an effect of age. Effects of exercise conditioning have been described in several studies (Anderson 1975, Bent et al., 1991, Grün et al., 1977, Hambleton et al., 1980, Siciliano et al., 1995). Whatever reason, the difference of the enzyme activities between the two age groups defined was not large enough to overcome individual variation and thus demonstrate significance. Neither did the absolute change of the enzyme activity in plasma of horses between warmup and fourth run or the relative change between warm-up and the run when the blood lactate concentration increased above $4 \mathrm{mmol} / \mathrm{l}$ correlate with $\mathrm{v}_{4}$ or $\mathrm{v}_{200}$ of the horses. And finally, between racing time record and the absolute or relative differences of plasma enzyme activities there was no correlation either. Thus, all indicators used demonstrated that the measurement of enzyme activities during and within a short period of time after exercise may not be of help to diagnose performance level of standardbred horses. Sampling the blood later after exercise than in this study or after another type of exercise than the one used may allow a better indication of the adaptation of horses to exercise conditioning and even of their competitive performance level. But, the likelihood is small. As a matter of fact, the type of exercise test used excerts a prolongued and not very severe stress on horses. It has been demonstrated that this type of exercise is more likely to induce large increases of the enzymes measured than exercise of short duration and more severe stress (Siciliano et al., 1995, Valberg et al., 1993). Therefore, effects of adaptation should be observable under these conditions.

The question about the most adequate time of blood sampling after exercise for the diagnosis of performance level of horses measuring plasma enzyme activities can not be answered yet because until now it has not been demonstrated that the measurement of plasma enzyme activities can help diagnose performance level in horses. Therefore it

\begin{tabular}{|c|c|c|c|c|c|c|c|}
\hline \multirow[t]{3}{*}{ Enzyme } & \multirow[t]{3}{*}{ Time of blood sampling } & \multicolumn{6}{|c|}{ Age group } \\
\hline & & \multicolumn{3}{|c|}{ Two-year olds } & \multicolumn{3}{|c|}{ More than two-year olds } \\
\hline & & Median & 10th & 90th & Median & 10th & 90th \\
\hline \multirow[t]{4}{*}{ CK } & After warm-up & 230 & 161 & 306 & 186 & 154 & 272 \\
\hline & After 4th run & $313^{*}$ & 205 & 811 & 195 * & 185 & 282 \\
\hline & After lactate $>4 \mathrm{mmol} / \mathrm{l}$ & 313 & 205 & 811 & 214 & 195 & 308 \\
\hline & 10 minutes after test & 266 & 221 & 986 & 234 & 186 & 392 \\
\hline \multirow[t]{4}{*}{ LDH } & After warm-up & 258 & 193 & 392 & 312 & 195 & 391 \\
\hline & After 4 th run & 340 & 188 & 438 & 277 & 224 & 453 \\
\hline & After lactate $>4 \mathrm{mmol} / \mathrm{l}$ & 340 & 188 & 438 & 360 & 207 & 450 \\
\hline & 10 minutes after test & 324 & 54 & 414 & 331 & 228 & 391 \\
\hline \multirow[t]{4}{*}{ AST } & After warm-up & 325 & 262 & 512 & 345 & 288 & 712 \\
\hline & After 4 th run & 361 & 274 & 559 & 342 & 292 & 746 \\
\hline & After lactate $>4 \mathrm{mmol} / \mathrm{l}$ & 361 & 274 & 559 & 354 & 312 & 760 \\
\hline & 10 minutes after test & 338 & 264 & 546 & 356 & 294 & 752 \\
\hline
\end{tabular}

Tab. 1: Plasma enzyme activities in standardbred horses of two years of age $(n=6)$ and older $(n=9)$ at different stages of an exercise test $(\mathrm{U} / \mathrm{l}$; median, 10th and 90th percentiles)

Enzymaktivitäten im Plasma von 2jährigen ( $n=6)$ und älteren Trabrennpferden $(\mathrm{n}=9)$ während verschiedener Phasen eines standardisierten Belastungstests (U/I, Median, 10- und 90-Perzentile)

\footnotetext{
* Mann-Whitney U-test demonstrated difference between groups at the level of $p<0.01$
} 
is not possible to define when blood samples should be taken for this purpose. The reason for taking the blood samples at the times described in this study is that they are well standardizable under practical field conditions where in general it is not possible to accompany a horse after exercise for more than 10-15 minutes.

In conclusion, under the practical conditions observed in this study it seems unlikely that the mesurement of plasma CK, LDH and AST activities allows to diagnose performance level of standardbred horses. The results indicate too that exercise conditioning in conjunction with age elicited an adaptation of the skeletal muscle system, reducing the increases of all the plasma enyme activities measured. Future studies will have to examine whether this is different in standardbred horses with recurrent rhabdomyolysis to advise trainers to change exercise conditioning, feeding and general management practice for such horses.

\section{References}

Anderson, M.G. (1975): The influence of exercise on serum enzyme levels in the horse. Equine vet. J. 7, 160-165.

Auvinet, B., Galloux, P., Michaux, J.M., Franqueville M., Lepage, O., Ansaloni-Galloux, A. and Coureau, C. (1991): Test d'effort standardisé de terrain pour cheveaux de concours complet (TEST). Science and Sports 6, 145-152.

Bent, E., Hambitzer, R. and Sommer H. (1991): Das Verhalten von belastungsinduzierten Blutwertveränderungen bei Pferden im Verlauf eines Trainingsjahres. Tierärztl. Umschau 46, 63-65.

Casini, L. and Greppi, G.F. (1996): Correlation of racing performance with fitness parameters after exercise tests on treadmill and on track in Standardbred racehorses. Pferdeheilkunde 12, 466-469.

Erickson, H.H., Erickson, B.K., Lundin, C.S., Gillespie, J.R. and Coffman, J.R. (1990): Performance indices for the evaluation of the equine athlete. In: Proc. Am. Ass. Equine Pract. 36, 457-469.

Freestone, J.F., Kammerling, S.G., Church, G., Bagwell, C. and Hamra, J. (1989): Exercise induced changes in creatine kinase and aspartate aminotransferase activities in the horse. J. Eq. Vet. Sci. 9, 275-280.

Grün, E., Schneider, J., Panndorf, H. und Preuße, C. (1977): Das Verhalten von Serumenzymen bei trainierten Galopprennpferden im Verlauf von zwei Rennjahren. Vet. Med. 32, 866-873.

Hambleton, P.L., Slade L.M., Hamar, D.W., Kienholz, E.W. and Lewis L.D. (1980): Dietary fat and exercise conditioning effect on metabolic parameters in the horse. J. Anim. Sci. 51, 1330-1339.

Harkins, M.R., Beadle, R.E. and Kamerling, S.G. (1993): The correlation of running ability and physiological variables in Thoroughbred racehorses. Equine vet. J. 25, 53-60.

Hatzipanagiotou, A., Lindner, A. und Sommer, H. (1991): LDH- und CK-Isoenzymmuster im Blutplasma von Pferden mit erhöhten CK-, LDH- und AST-Aktivitäten. Dtsch. tierärztl. Wschr. 98, 284-286.

Islas, A., Perez, R., Rojas, R., Jara, C., Mora, G., Recabarren, S. and Hetz, E. (1992): Actividad sérica de creatina fosfoquinasa, aspartato aminotransferasa, dehidrogenasa láctica y fosfatasa alcalina en equinos mestizos de tiro sometidos a esfuerzo prolongado de tracción. Arch. Med. Vet. 24, 53-59.

Jeffcott, L.B. (1974): Haematology in relation to performance and potential. 2. Some specific aspects. J. S. Afr. Vet. Assoc. 45, 279-286.

Lindholm, A. (1987): Pathophysiology of exercise induced diseases of the musculoskeletal system of the equine athlete. In: Gillespie, J.R., and N.E. Robinson (Eds.): Equine Exercise Physiology 2. ICEEP Publications, Davis, California: 711-727.
Lindner, A. (1996): Measurement of plasma lactate concentration with Accusport. Equine vet. J. 28, 403-405.

Lindner, A. (1998): $v_{4}$ allows to distinguish better the performance level of Standardbred horses than $v_{200}$. In: Lindner, $A$. (Ed.): Equine Sports Medicine and Science. Wageningen Press, ISBN 90-74134-56-4, 251-253

Persson, S.G.B. (1982): Evaluation of exercise tolerance and fitness in the performance horse. In: Snow, D.H., S.G.B Persson, and R.J. Rose (Eds.). Equine Exercise Physiology 1. Granta Editions, Cambridge U.K., 441-457.

Persson, S.G.B. (1997): Heart rate and blood lactate responses to submaximal treadmill exercise in the normally performing standardbred trotter - age and sex variations and predictability from the total red blood cell volume. J. Vet. Med. A 44, 125-132.

Persson, S.G.B., Essen-Gustavsson, B., Lindholm, A., McMiken, D. and Thornton, T.R. (1983): Cardiorespiratory and metabolic effects of training of Standardbred yearlings. In: Snow, D.H., S.G.B. Persson, and R.J. Rose (Eds): Equine Exercise Physiology 1. Granta Editions, Cambridge U.K., 458-469.

Rose, R.J. and D.R. Hodgson, D.R. (1982): Haematological and plasma biochemical parameters in endurance horses during training. Equine vet. J. 14, 144-148.

Rose, R.J., Hodgson, D.R., Sampson, D. and Chan, W. (1983): Changes in plasma biochemistry in horses competing in a $160 \mathrm{~km}$ endurance ride. Aust. vet. J. 60, 101-105.

Siciliano, P.D., Lawrence, L.M., Danielsen, K., Powell, D.M. and Thompson, K.N. (1995): Effect of conditioning and exercise type on serum creatine kinase and aspartate aminotranferase activity. Equine vet. J. Suppl. 18, 243-247.

Sloet van Oldruitenborgh-Oosterbaan, M.M., Wensing, T. and Breuking, J. (1987): Standardized exercise test on a track to evaluate fitness and training of saddle horses. In: Gillespie, J.R., and N.E. Robinson (Eds.): Equine Exercise Physiology 2. ICEEP Publications, Davis, California, 68-76.

Snow, D.H., Kerr, M.G., Nimmo, M.A. and Abbott, E.M. (1982): Alterations in blood, sweat, urine and muscle composition during prolonged exercise in the horse. Vet. Rec. 110, 377-384.

Szarska, E. (1994): Tentative assessment of fitness in endurance horses on the basis of selected blood indices and ride results. Adv. Agricultural Sci. 3, 25-30.

Valberg, S., Häggendal, J. and Lindholm, A. (1993): Blood chemistry and skeletal muscle metabolic responses to exercise in horses with recurrent rhabdomyolysis. Equine vet. J. 25, 17-22.

\section{Dr. Arno Lindner}

Im Eichholz 10

D-53127 Bonn

Germany

Tel: +49-228-29925

Fax: $+49-228-284761$

E-mail: arnolindnerbonn@t-online.de

\section{Dr. Asterios Hatzipanagiotou}

Associate Professor of Animal Biochemistry

Section of Animal Production

School of Agriculture

Aristotelian University of Thessaloniki

Greece

Tel: +30-31-678373

Fax: $+30-31-678373$ 